\title{
Correction to: Linking Wine Culture and Geoheritage-Missing Opportunities at European UNESCO World Heritage Sites and in UNESCO Global Geoparks? A Survey of Web-Based Resources
}

\author{
Edyta Pijet-Migoń ${ }^{1}$ (I) $\cdot$ Piotr Migoń ${ }^{2}$ (I)
}

Published online: 5 August 2021

(c) The European Association for Conservation of the Geological Heritage 2021

Correction to: Geoheritage (2021) 13:71

https://doi.org/10.1007/s12371-021-00594-4

In Table 1 of this article, a layout error has occurred. Row no. 11 is incorrectly positioned and the integrity of row no. 10 was also affected. Also, the ORCiD of Piotr Migon that was originally missing has been reflected.

The original article has been corrected.

The original article can be found online at https://doi.org/10.1007/ s12371-021-00594-4

Edyta Pijet-Migoń

edyta.migon@wsb.wroclaw.pl

1 Institute of Tourism, WSB University inWrocław, Fabryczna 29-31, 53-609 Wrocław, Poland

2 Institute of Geography and Regional Development,

University of Wrocław, pl. Uniwersytecki 1, 50-137 Wrocław,

Poland 